\title{
Development of Colored Shuttlecocks as a Badminton Learning Media
}

\author{
Devi Fitriyanti \\ Postgraduate Program \\ Universitas Negeri Medan \\ (UNIMED) \\ Medan, Indonesia \\ devifitriyanti19@gmail.com
}

\author{
Nurhayati Simatupang \\ Postgraduate Program \\ Universitas Negeri Medan \\ (UNIMED) \\ Medan, Indonesia
}

\author{
Agung Sunarno \\ Postgraduate Program \\ Universitas Negeri Medan \\ (UNIMED) \\ Medan, Indonesia
}

\begin{abstract}
This research was conducted at the Medan Sinar Husni Private Middle School and the process of making shuttlecocks in Malang. The research at Sinar Husni Middle School in Medan will be conducted in February 2018 and the manufacturing process will be in December 2018. The stages of this research include collecting poultry feather waste materials with the main objective of this research is the development of colored shuttlecocks as a medium for learning badminton.

The type of research used is development research (Research and Development), with a sample of learning experts / PJOK teachers testing small groups of 6 teachers, and large group trials of 6 teachers, reaching $82.43 \%$ with valid criteria can be used. Experts on shuttlecock (Badminton Trainer) products amounted to $97.65 \%$ with valid criteria can be used. The small sample trial group of 10 students from Medan's Sinar Husni Private Middle School reached $71.6 \%$ with an effective level, and a sample of a large group of 20 students from Medan's Sinar Husni Private Middle School reached $84 \%$ with a very effective level. Then from the feasibility test reached an average number of $90.88 \%$ with valid criteria to be used. On the basis of the data obtained, the development of colored Shuttlecock products was declared feasible to be developed as one of the learning media in badminton game material in Physical and Health Education subjects in Junior high school.
\end{abstract}

Keywords : Colored Shuttlecocks, Learning Media, Badminton

\section{INTRODUCTION}

Badminton is a worldwide sport with the marking of this sport starting to be competed at the Olympic Games in Barcelona in 1992. Although badminton has actually been played for a long time, but so far research on badminton is still very little, even though in the fierce competition the world badminton achievements require. many studies that will be useful for fostering achievement (Ahmad Susanto, 2016: 15).

One means of badminton or a tool that is played is shuttlecock (kok). Shuttlecocks are usually made of feather that has been made in the factory. The feathers commonly used in making shuttlecocks include feathers from geese, ducks, feathers, native chickens, broilers. Waste of feather poultry is generally obtained from breeding / poultry farms as a producer of feathers for shuttlecock material. Based on the explanation above, this research is intended to develop colored shuttlecocks as a medium for learning badminton.

One by-product that is widely used as an industrial material is poultry feathers. Feather waste consists of $6 \%$ of the live weight of poultry. Cut chicken feathers / ducks, ducks, geese or geese can be obtained from the slaughter of poultry in traditional markets, or poultry slaughterhouses. In general, poultry feathers which are poultry slaughter waste in traditional markets have not been utilized. Basically, poultry feather waste has 3 basic colors, namely white, black, and brown. Black and brown feather poultry wastes cannot be used at all, so there is a build-up of wastes in traditional markets and waste disposal.

Based on observations in a number of shops providing badminton sport facilities, shuttlecocks with feathers and goose feathers have not yet been found. Then, in the city of Medan there is no known factory or industry that makes or produces shuttlecocks because so far shuttlecocks circulating in the market are made from Central Java or East Java (Malang).

Shuttlecocks consist of a number of constituent materials, namely feather entuk, which are basically white feather entok sent through the State of Taiwan and China, each shuttlecock consists of 16 strands of fur. Then the dop (cork) for the place to put the fur is sent from China, the ribbon used on the outer hubcap, the shuttelcock label, the thread is used to sew the feathers to be strong when played. The next material is glue that consists of special glue to glue the yarn with feathers, and Fox glue to glue the label with a hubcap. The final material is the shuttlecock wrapper and the shuttlecock cover. The stages of making shuttlecocks begin with the purchase of fur from suppliers in Taiwan and China. The production process starts from washing the fur, drying, cutting the pattern, shaping the fur, straightening the fur, assembling, servicing, sewing the fur, gluing, installing labels and ribbons, weighing the shuttlecock weighing 49 grams each, and the final process is packaging. The equipment used consisted of feather cutters, scissors, forceps, hair straighteners and weighing tools. The process of making shuttlecocks above is mostly done by neighbors around the research object. 
One effort to increase student interest in playing badminton is to use a shuttlecock that is different from shuttlecocks in general, which are used in white. The use of colored shuttlecocks, especially black, made from poultry feather waste has never been done and is played by students. For this reason, a colored feather waste product development will be carried out which will be applied to students in schools. Aside from being a means of attracting students' interest in badminton, naturally the development of colored shuttlecock products will reduce colored feather waste that has not been used because in general only white poultry feather waste is used to make shuttlecock material.

\section{Research Objectives}

Based on the background explanation of the research problem and the focus of the research detailed in the research formulation. Then the objectives in this study are:

1. To produce the use of colored shuttlecocks as a useful and quality badminton learning media on PJOK subjects that are suitable for use.

2. To increase motivation, increase attractiveness, and interest of students to participate in PJOK learning activities on the problem of badminton games through colored shuttlecock media.

3. The use of colored shuttlecock products has good durability as a medium or tool in badminton games, and has products that are more effective and efficient for use as learning media for PJOK.

4. The teacher will find it easier to provide motivation and enthusiasm to students to do PJOK learning activities especially badminton games using the colored shuttlecock tool.

\section{INFORMATION LITERACY}

Badminton as one of the popular sports games and is popular with Indonesian people, ranging from children to the level of parents, men and women. Badminton quickly spreads in remote areas due to this badminton sport, the State of Indonesia can be known internationally, namely by the achievements achieved by Indonesian athletes. With the badminton community, efforts to achieve badminton achievement must be continuously promoted and improved in order to maintain and improve the achievements that have been obtained, in order to carry the fragrant name of the State of Indonesia at the world level.

Equipment in badminton has always been a part of the discussion of badminton learning materials. In order for a badminton game to run smoothly, the following types of equipment are commonly used by badminton players:

\section{1). Field}

Badminton court measuring 13.41 x $6.1 \mathrm{~m}$ which is divided into two regions and separated by a net. Badminton court net height is $1.55 \mathrm{~cm}$.

2). Clothes
Like other athletes in general, every badminton player has the main equipment and extras when appearing in a game or match. Shirts and pants are classified as the main accessories, while their hands, headbands, and knee pads can be called additional.

\section{3). Badminton shoes}

Shoes are an important part in the game of badminton. Comfortable shoes and socks will help the player in every important step both for stability while attacking and defending against an opponent's smash. A strong footing can prevent players from injury.

4). Racket

Racket is a must-have equipment if you want to play badminton. The racket is used to hit and deflect the shuttlecock so it does not fall in the area of defense.

5). Shuttlecock / kok

"How come" is a term commonly used in Indonesia to refer to shuttlecocks. Shuttlecocks which are usually made from factory-made goose feathers generally already have the standards set by the IBF. The weight of the shuttlecock is around 5.67 grams. Goose feathers or chicken feathers stuck in the cork wrapped in white skin amounted to between 14-16 pieces, and tied two ropes so that they are not easily separated.

The 2013 curriculum or Character Based Education is a new curriculum that was coined by the Indonesian Ministry of Education and Culture to replace the Education Unit Level Curriculum. 2013 curriculum is a curriculum that prioritizes understanding, skills and character education, students are required to understand the material, be active in discussions and presentations and have high discipline manners.

Therefore, teachers are not justified in avoiding their obligations as instructors and educators to appear before students with all their personalities. It often happens that a teacher is not creative in using teaching methods. They are quite satisfied with conventional methods so that they are less motivating for students to follow the teaching and learning process. They rely on lecture methods that are very boring so there is no interesting and fun teaching and learning process in the classroom.

As revealed in the Big Indonesian dictionary (2007: 710), utilization is the prefix of the word benefit, which means use or use, so that it makes a material that is useful and useful or becomes more useful. Thus, utilization is an act to utilize something so that it is of use or becomes more useful. The problem that will be investigated is how the utilization of poultry feather waste becomes more useful as a material for making colored shuttlecocks on badminton.

Chicken feather waste that is not used and thrown away in the environment around the Chicken Slaughterhouse can cause unpleasant odors. In addition, it becomes a nesting place, and usually very disturbing human health. Another impact, which can reduce soil quality because chicken feather waste is very difficult to degrade in the environment or the decomposer process takes a long time. 


\section{RESEARCH METHOD}

\section{Place of Research}

This research was conducted at Sinar Husni Private Junior High School and the making of shuttlecock media in Malang City, East Java.

\section{Research time}

The time of this research was conducted in December 2018 in Malang and February 2019 at the Sinar Husni Private Junior High School in Medan.

Target users or who are often referred to as users in this shuttlecock development research are students of Sinar Husni Private Junior High School by only involving 1 class. This is done to more effectively and efficiently process the resulting product trials so that it is well known whether the developed shuttlecock products are appropriate or not used as learning media.

This type of research method used in the research development of colored shuttlecocks as badminton learning media uses research and development methods (Research and Development) which aim to develop and validate learning products. Research and development in this study uses the Research and Development (R\&D) development model of Brog and Gall which consists of ten steps including:

Preliminary studies are by conducting and collecting field studies (observations, interviews, and documentation).

Planning with product development (the process of preparing the selection of poultry feathers for media, and the process of making colored shuttlecocks).

Develop initial product or product validation (utilizing colored feather waste and done by experts).

Conducting field trials beginning / small field with effectiveness and comfort (using subjects as many as 10 people, namely Sinar Husni Private Junior High School students by meeting the requirements).

The first phase of product revision was carried out by researchers (questionnaires, interviews, and documentation).

Conducting a large field trial that is knowing the quality of shuttlecocks (using as many as 20 subjects or students of Sinar Husni Private Junior High School).

Conduct a second phase of product revisions (interviews, questionnaires, and documentation).

Field trials or badminton feasibility tests to determine effectiveness, comfort, speed, endurance, and vision.

Data Analysis Techniques

The data that has been collected is then analyzed using quantitative descriptive analysis obtained from the results of an evaluation questionnaire filled out by media experts, experts, badminton experts, and PJOK learning experts regarding the product being developed. The formula used to analyze this data is as follows:

Formula for obtaining data per test subject

$\mathrm{P}=\left(\sum \mathrm{X}\right) /\left(\sum \mathrm{Xi}\right) \mathrm{x} 100 \%$

Information:

P: Percentage of overall results of evaluation of trial subjects $\sum X$ : The total number of test subjects' answers in all aspects assessment $\sum X i$ : The total number of maximum scores of trial subjects in the whole

assessment aspects

100\%: Constants (Nana Sudjana, 1990: 131)

The formula for processing the results of the responses or evaluations of each PJOK teachers from the results of the product questionnaire responses can be used with the formula: Value $=$ Number of Scores $/$ Skortotal $\mathrm{x} 100$

For the average category of productivity values are as follows: Table 3.8. Product Productivity Category

Category Value $\geq 80$ Very Effective

60 - 79 Effective

40 - 59 Effective

30-39 Less Effective

$<29$ Very Less Effective

\section{RESULT AND DISCUSSION}

The use of colored shuttlecocks as a learning medium is indeed needed in increasing student motivation. This is in line with what was stated in the results of Husna Yuwida's scientific research in 2016 with the research title: Development of Making Rainbow Shuttlecocks for Early Childhood. Where the results of research into the development of the rainbow shuttlecock media for early athletes is categorized as suitable as a training medium to provide understanding of badminton for early athletes. This can be seen from the results of the assessment of material experts $92.83 \%$ and $97.00 \%$ media experts and based on the results of field trials of $94.92 \%$.

Thus, the development of colored shuttlecock learning media is indeed needed and is able to increase student learning motivation in badminton game subject matter. In addition, it can be understood that the success of student learning at school is closely related to the existence of learning media that support so that students more easily understand the material being taught.

Learning media in the form of black shuttlecocks become very urgent to be used during the teaching and learning process in introducing badminton games to students. It is based on the use of learning media that are different from usual and have become characters students will be happy with something new and different from usual, and this colored shuttlecock is very appropriate to be used as a learning media on badminton game material.

Colored Badminton (shuttlecock) As Learning Media (Feasibility Test)

After the black shuttlecock product goes through several stages of assessment by experts and also testing small groups and large groups, the black shuttlecock product can be developed into a product that is useful for the interests of the game in learning Physical Education at junior high school level. The black shuttlecock product which is developed is as much as possible in accordance with the suggestions and input from experts and students' needs in playing badminton. 
To find out the results of the feasibility test of developing a black shuttlecock product as a learning medium, the following data are obtained through experts and students.

Based on the data in the table above where the feasibility test of the colored shuttlecock product is carried out it is known that from the media experts gave a value of $96.5 \%$ with very valid criteria. User experts or PJOK teachers gave a value of $91.23 \%$ with valid criteria and as many as 20 students gave grades of $84 \%$ with very effective criteria, so that the average worthiness obtained was $90.98 \%$ with very decent criteria. This shows that the development of colored shuttelcock products using poultry feather waste as a medium for learning badminton is very feasible to be developed in the future.

Shuttlecock product innovation is believed to be able to increase students' motivation and enthusiasm in learning and doing badminton games. Learning media innovation is very important because besides being a form of teacher's creativity, it is also very helpful in increasing student motivation and learning enthusiasm. If during this time students were introduced to the techniques of playing badminton according to their respective levels and playing games with shuttlecocks which are commonly done in white, of course it is a common thing because it is always seen anywhere and in games and matches from low level to world level .

On the other hand, the development of black shuttlecock products is very useful in reducing the amount of unused feather waste and waste wastes, because so far only white feathers are used, with new products will be very able to reduce waste that has been wasted. Then, in terms of economics, the development of shuttlecock products made from black feathers will be able to boost the community's economy both as waste collectors, product makers, and also sellers who market black shuttlecock products.

However, product development at an early stage is still considered imperfect so there is a need for product revisions that are carried out with the advice and input from experts. After going through the product revision stage, a large group trial was conducted to see the quality of the colored shuttlecock products and from the results of the large group trial the value was $84 \%$ with very effective criteria.

After conducting a large group trial, the product feasibility test is carried out by looking at how large the color shuttlecock is as a learning medium. Through the instruments given to media experts, PJOK experts and also students, the results obtained are $88.9 \%$ with very decent criteria. This shows that the development of colored shuttlecock products is very feasible, especially as a tool or learning media in badminton games for junior high school students.

\section{REFERENCES}

[1] Abubakar et al. 2000. Survey of Potential Availability of Chicken Feathers, Processing Methods and Cutting of Chicken Livestock in TPA. T.A. Research Report 1999/2000. Bogor: Animal Research Institute.

[2] Agus Salim. 2008. Smart Book Badminton. Bandung: Shades.

[3] Ahmad Susanto. 2016. Learning Theory and Learning. Jakarta: Prenada Media Group.

[4] Aksan, Hermawan. (2012). Proficient Badminton. Bandung: Shades of Scholar.

[5] Anderson, Ronald H. 1987. Media Selection and Development for Learning. Jakarta: Open University in collaboration with CV. Rajawali.

[6] Ari Purwanto. 2007. Social Research and Education Instruments: Development and Utilization. Yogyakarta: Student Library.

[7] Asim 2001. Systematics Research Development. Malang: Malang State University Research Institute.

[8] Azhar Arsyad. 2010. Learning Media. Jakarta: Rajagrafindo Persada.

[9] Bram Palgunadi. 2008. Product Design 4: Preparation and Planning. Bandung: ITB

[10] Dimyati and Mudjiono. 2013. Learning and Learning. Jakarta: Rineka Cipta

[11] Dina, Indriana. 2011. Variety of Learning Media Aids. Yogyakarta. Diva Press

[12] Dini Siswani Mulia, 2016. Utilization of Chicken Feathers Waste into Fish Feed Materials by Fermentation of Bacillus Subtilis. Human and Environmental Journal, Vol. 23, No.1 March 2016.

[13] Endah Permata Sari. 2015. Utilization of Chicken Feather Waste as Ruminant Animal Feed. Indon Pros Mas Nas Biodiv Journal, Volume 1 Number 1 March 2015.

[14] Hamalik, Oemar. 2014. Curriculum and Learning. Jakarta: BumiAksara

[15] Herman Subardjah. 2001. Badminton. Yogyakarta: Ministry of Education and Culture.

[16] Johnson. 1984. Badminton Playing Guidance. Jakarta: Mutiara Sumber Widya.

[17] Muhajir. 2007. Sports and Health Physical Education. Yudistira: Bandung.

[18] Pudji Hastuti. 2009. The Special Olympics Badminton Branch. Jakarta: Special Olympics Indonesia.

[19] Sadiman, et al. (2008). Educational Media: Definition, Development and Utilization. Jakarta: PT Raja Grafindo Persada

[20] Badminton History, Badminton History: Badminton Game Rules. 2013. Accessed: 28 September 2014 http: // play technique. blogspot. com / 2012/05 / history-badminton-history of badminton.html

[21] Sugiyono, 2010. Educational Research Methods. Batur Alfabeta.

[22] Suharsimi Arikunto. 2006. Research Procedure A Practical Approach. Jakarta: Rineka Cipta.

[23] Tony Grice. 1996. Badminton Practical Guidelines for Beginners and Advanced. Jakarta: Raja Grafindo Persada.

[24] Law No. 23 of 1997 concerning Environmental Management.

[25] Law Number 12 of 2012 concerning Higher Education Presidential Regulation Number 8 of 2012 concerning the Indonesian National Quality Framework (KKNI) Presidential Regulation Number 19 of 2005 concerning National Education Standards.

[26] Wisri Puastuti. 2007. Chicken Feather Processing Technology and Its Utilization as a Source of Ruminant Feed Protein. Wartazoa Journal Vol. 17 No. 2 years. 2007: 53. 